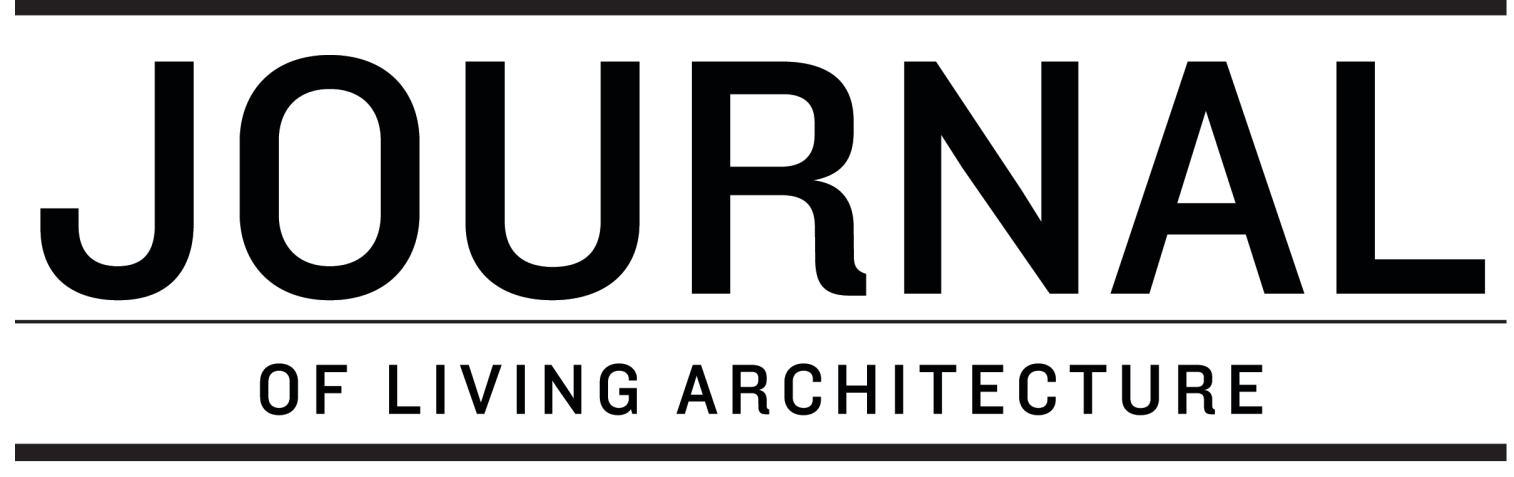

A GREEN INFRASTRUCTURE FOUNDATION PUBLICATION

\title{
Bench-study of green-wall plants for indoor air pollution reduction
}

\author{
Fraser Torpy ${ }^{1}$, Michael Zavattaro ${ }^{2}$ \\ ${ }^{1}$ Senior Lecturer Program Director Environmental Biology / Environmental Sciences, Plants and \\ Environmental Quality Research Group, Faculty of Science University of Technology Sydney \\ Fraser.Torpy@uts.edu.au \\ ${ }^{2}$ School of Life Sciences, University of Technology Sydney, PO Box 123, Broadway, NSW 2007, \\ Australia
}

\begin{abstract}
Potted-plants have the potential for improving indoor air quality (IAQ), however there has been little research on the performance of green-walls as indoor biofilters. The aim of this investigation was to compare rates of air pollutant reduction with two commonly used indoor species, and to assess the effects of added substrate airflows on the capacity of green-wall modules to remove two prevalent indoor airborne contaminants - particulate matter (PM), and volatile organic compounds (VOCs), using benzene as model. The species tested were Chlorophytum comosum (Spider Plant) and Epipremnum aureum (Pothos). The results showed that each species could significantly reduce increasing doses of PM, with or without augmented substrate airflow, however benzene removal rates decreased with increasing aeration. The findings provide a first assessment of the ability of green-wall plants to reduce indoor air pollution, and responses to two types of pollutant, particulate and gaseous.
\end{abstract}

Keywords: green-wall, indoor air, indoor air quality (IAQ), biofiltration, particulate matter (PM), volatile organic compound (VOC) 


\section{INTRODUCTION}

It is predicted that the present world population of $\sim 7.3$ billion will rise to $\sim 9.7$ billion by 2050 , and that over the period the proportion of urban dwellers will increase from the current $54 \%$ to $60 \%$ (UN DESA 2015). Urban living offers better opportunities for employment, health facilities and education (World health Organisation; WHO 2010). Nevertheless the losses of greenspace and planted streetscapes (Chiesura 2004), the consolidation and densification of buildings (Abel 2010), and increased energy consumption, noise, and air pollution (Wong et al. 2010), have significant negative environmental, social, and health impacts. And since city dwellers spend on average $90 \%$ of time inside buildings, indoor air quality (IAQ) plays a crucial role in urban health and wellbeing (Bernstein et al. 2008).

The USEPA (2014) estimates that about $90 \%$ of urban air pollution is produced by fossil fuel combustion, and the agency has designated six internationally important Criteria Air Pollutants hazardous to health and the environment. They include: particulates (PM); ozone; carbon monoxide; nitrogen oxides; sulfur oxide; and lead (USEPA 2016). To these could be added volatile organic compounds (VOCs), which can cause respiratory problems, cancers, liver and kidney damage, and other adverse health effects (Evuti, 2013). Air pollutants readily diffuse indoors, mixing with more contaminants from indoor sources. However, there are no national standards for VOCs in the USA in non-industrial settings (USEPA, 2017), and no regulations in Australia concerning indoor air quality (Kearney et al. 2011).

The major source of PM is from vehicle exhaust fumes (Kurniawan and Schmidt-Ott 2006; Cheng et al. 2008), which produce city hazes. The toxicity of PM varies with the make-up of mixtures of organic, mineral and metal particles (Fann et al. 2009; Ashraful et al. 2015). Human health risks are associated both with $\mathrm{PM}_{10}$ (i.e., particles $\leq 10 \mu \mathrm{m}$ diameter) and $\mathrm{PM}_{2.5}$ (<2.5 $\mu$ m diameter) (WHO 2013; NSW Health 2014; NSW EPA 2015). Although building ventilation airstreams filter much of the incoming dust, some PM penetrates buildings, and indoor dust is released from, e.g., insulation materials, heating and ventilation systems, papers, books etc., and human presence.

Fossil fuel emissions are also a primary source of airborne VOCs (Aust. Gov. Dept. Ind., Innov., Sci. 2011), the most commonly encountered types being the BTEX group: Benzene, Toluene, Ethyl benzene, and Xylene. The VOCs diffuse indoors, and mix with others from indoor sources, e.g. adhesives, solvents, and outgassing from synthetic furniture, finishes and furnishings (Wheeler et al., 2013). Indoor air pollution can be more than 5 times higher than in the surrounding outdoor air (US EPA 2016). Hundreds of VOCs have been identified in indoor air (Zhang and Smith 2003; Minnesota Dept. Health 2017), and because of its prevalence and toxicity, benzene is widely used as a surrogate pollutant for research purposes (Gonzalez and Kimura, 2003; Smith, 2010), and was so used in this study.

For Benzene, the World Health Organisation (WHO 2010) recommends a "no-safe-level" of exposure, and states that the increased risk of cancer per $1 \mu \mathrm{g} / \mathrm{m}^{3}$ increase in airborne benzene, is 1 per million of population. The average range of ambient outdoor benzene 
concentrations in the Sydney CBD, has been recorded as from about 4.8 to 80.5 ppbv (NSW Health, 2004). Benzene can cause leukaemia and other cancers, along with damage to the immune system, endocrine malfunction, and reproductive disruptions (Bahadar et al 2014); and the likelihood of such diseases is correlated with proximity to urban centres.

It is well established that outdoor plants can remove urban air pollutants (e.g. Aydogan and Montoya 2011; Irga et al 2013), including particulate matter (PM) (Escobedo and Nowak 2009; Dzierżanowski et al 2011; Irga et al., 2015). In addition, laboratory research has demonstrated the effectiveness of potted plants in reducing all types of indoor air pollution (Wolverton and Wolverton 1993; Wood et al 2006; Orwell et al 2006; Tarran et al 2007; Torpy et al 2014). Indoor plants have been used for over a century in commercial buildings, for aesthetic and psychological purposes (Aitken et al 1989; Knight and Haslam 2010). However research on their use plants to improve indoor air quality (IAQ) has been very limited., and some authors have suggested that an impractically large number of potted plants would be required to produce a positive effect (e.g. Llewellyn and Dixon 2011).

Nevertheless, several studies have reported their beneficial effects on IAQ (Darlington et al 2001; Soreanu et al 2013; Pérez-Urrestarazu et al 2016). In addition, over the last two decades the use of interior green-walls in commercial and public buildings has increased steadily for aesthetic purposes (Loh 2008; Pérez-Urrestarazu et al 2016).

Over the last three decades there has been an increase in the indoor installation of 'plantwalls' (i.e., green-walls, living-walls, bio-walls, or vertical garden). Since plant-walls can provide a greater density of plants per unit floor area than potted plants, and greater atmospheric exposure of their substrate, it might be expected that they could bring greater beneficial effects on air quality than potted plants occupying an equivalent space. Indoor green-walls without additional airflow, i.e. in 'passive' mode, rely on diffusion of ambient air to the static array of leaves and substrates (Soreanu et al 2013). It has been suggested, that pollution reduction in such green-walls is likely to be very slow (Llewellyn and Dixon 2011), or vary with air-conditioning flows. The novel, active modular plant-wall system investigated here, can provide substrate airflows through planted-wall modules by using an electric fan which forces air outwards through the substrate/rhizosphere and then foliage. This arrangement differs from the earlier one of Darlington et al. (2001), which utilised a trickling nutrient solution to draw polluted air towards a biofilter.

It is estimated that about $40 \%$ of the total energy consumption of commercial buildings, and $70 \%$ of base building electricity use, are from air-conditioning energy usage (Ind. Gov. Aust. 2013). Developing a complementary biofiltration system that could assist in improving IAQ while reducing loads on such systems, would be a significant step towards improving building sustainability. The phytoremediation of indoor air pollution is not yet a recognised technology, however appropriate horticultural biotechnology can be developed for its use in contributing to good IAQ. 


\section{MATERIALS AND METHODS}

The modular green-wall modules, containing C. comosum or E. aureum, were supplied by Junglefy Pty Ltd ('Junglefy Breathing Wall'; Sydney, Aust.). The plants had been nurserygrown in the modules for 8 months before being brought to the laboratory for testing.

Between laboratory tests the planted-modules were maintained in a rooftop glasshouse, with average temperature $23.5 \pm 3.5^{\circ} \mathrm{C}$; relative humidity of $68 \pm 15 \%$; and midday light intensity of $90 \pm 10 \mu \mathrm{mol} . \mathrm{m}^{-2} . \mathrm{s}^{-1}$. The modules were watered to saturation once weekly.

The module frames were composed of polyethylene $\left(500 \times 500 \times 130 \mathrm{~mm} ; 0.25 \mathrm{~m}^{2}\right)$, containing 16 cavities for single plants, using a coconut-fibre based substrate (Figs. 1a, b). A high-density polyethylene membrane net gave interior support for substrate and plant. A trough along the top of the module allowed for watering and liquid fertiliser applications, draining beneath to waste. The in-built substrate ventilation fans were $72 \mathrm{~mm}$ diameter (brushless DC units; Fantech TEF-100 Inline Fan, Aust.), attached to a duct in the centre rear surface of the module. The fans produced airflows of either 4.5 or $9.0 \mathrm{~L} / \mathrm{s}$.

For PM removal rates, three ventilation conditions were tested: passive mode, i.e., no added cross-ventilation; and two active modes, with either rate of airflow through the substrate. For benzene removal, rates were compared in passive mode, and with an airflow of $9.0 \mathrm{~L} / \mathrm{s}$. Testchamber temperatures were maintained at $23-26^{\circ} \mathrm{C}$. Concentrations of the two pollutants in the ambient laboratory air were also measured, for background comparison.

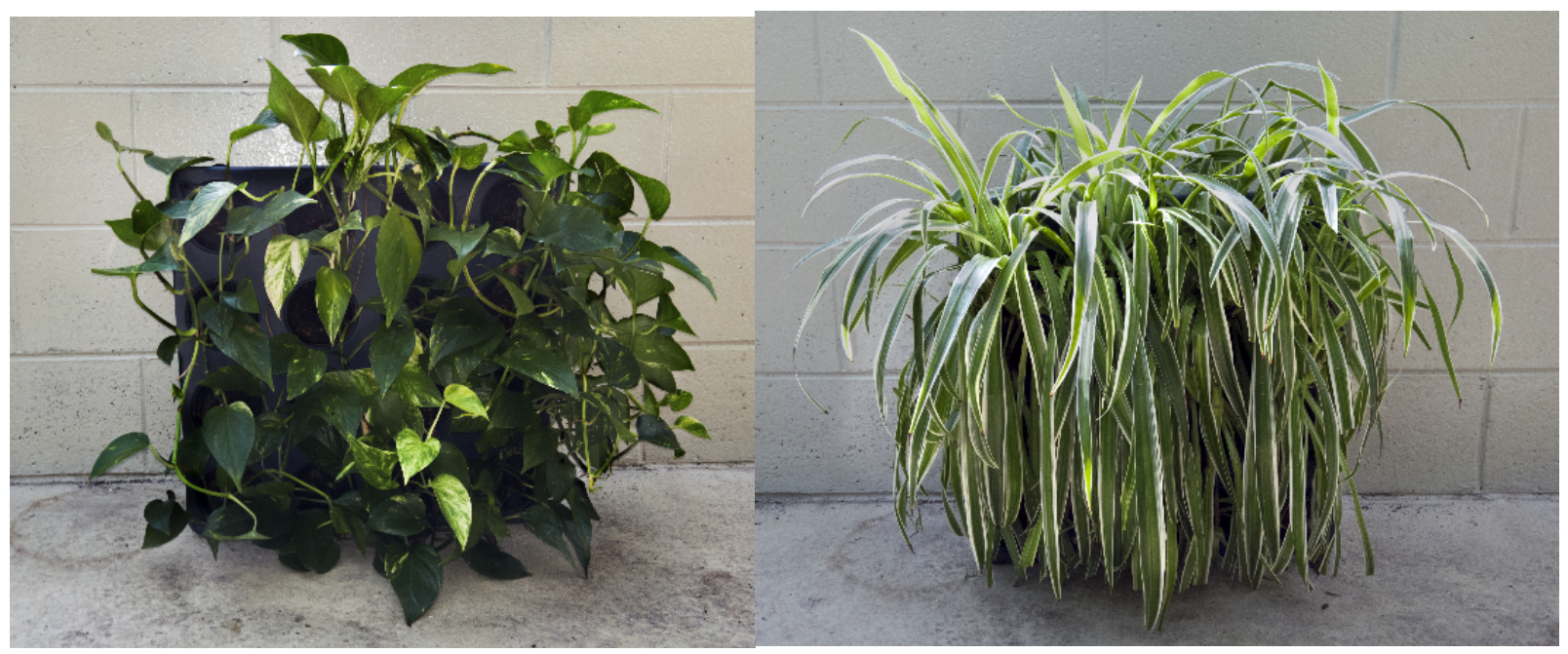

Figure 1: Green-wall modules, with: (a) Epipremnum aureum; (b) Chlorophytum comosum.

For each test, a single plant-module was placed in a sealed bench-top test-chamber $(0.6 \times 0.6$ x $0.6 \mathrm{~m} ; 0.216 \mathrm{~m}^{3}$ ) (Fig. 2). The test-chamber had a lid on a steel frame, which was sealed with adhesive foam-rubber tape and adjustable metal clamps. A sealed rubber port on the front of each chamber (see Fig. 2), enabled injection and timed samplings of test pollutants, by syringe. The test-chamber was fitted with a $100 \mathrm{~mm}$ diam. fan, to maintain pollutant distribution within the chamber atmosphere, and with a light intensity of $100 \mu \mathrm{mol} \mathrm{m}^{-2} \mathrm{~s}^{-1}$ 
(4750 lux; Sylvania M59R $400 \mathrm{~W}$ metal arc discharge lamp). Between tests, chambers were cleaned using 3 detergent/water washes followed by 5 (70\%) alcohol washes.

Three replicate planted-modules were used in every trial. Each module was selected randomly from the planted stock in the greenhouse, watered to field capacity in the laboratory, and drained for 1-hour before being placed in the test-chamber (Fig. 2). After the test, that planted module was not used again.

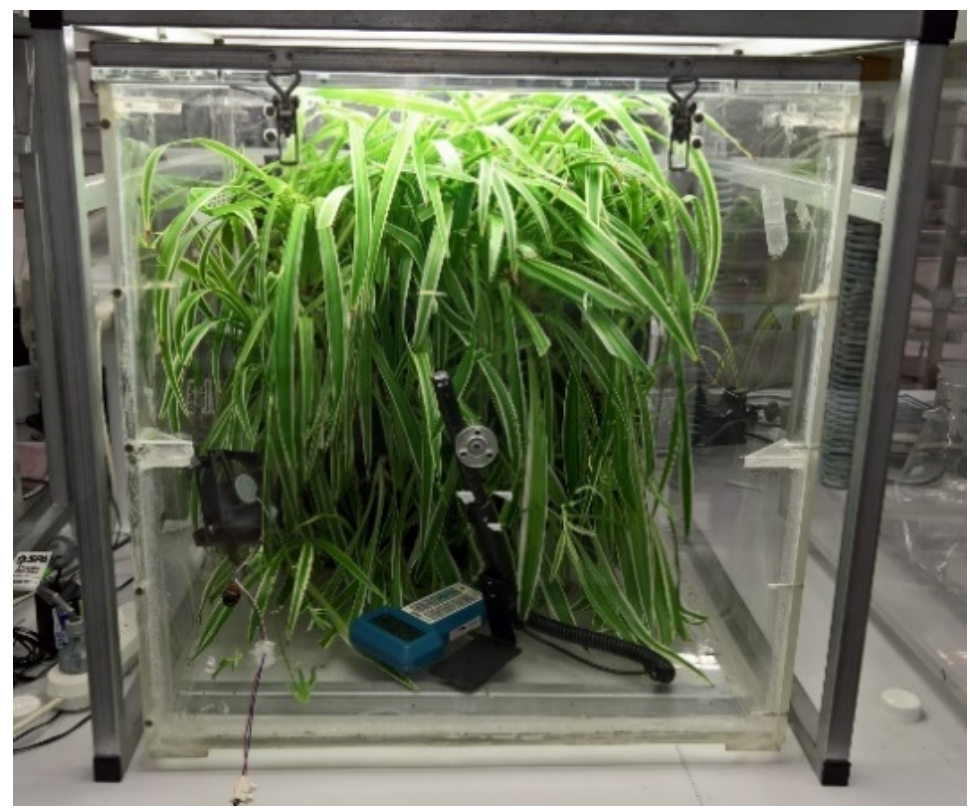

Figure 2: Sealed test chamber, with module containing C. comosum.

\section{Pollutant doses and measurements}

Particulates Samples of airborne PM were produced by burning a small amount of pumpgrade diesel fuel in a glass spirit burner, and collection of the effluent gas into a large glass vessel. The vessel was then rested for $5 \mathrm{~min}$ to allow the precipitation of larger particles, after which $\sim 50 \mathrm{~mL}$ of air containing suspended particles was injected into the test-chamber. This procedure gave a chamber air concentration of approximately $1,000 \mu \mathrm{g} / \mathrm{m}^{3}$ of PM, with a range of particle sizes including $\mathrm{PM}_{10}$ and $\mathrm{PM}_{2.5}$. Rates of $\mathrm{PM}$ reduction were measured using a DustTrak II Aerosol Monitor (TSI, Shoreview, Minnesota), which was sealed into the testchamber. Plantless test-chamber PM reduction tests were first conducted to determine the natural deposition rates of $\mathrm{PM}_{10}$ and $\mathrm{PM}_{2.5}$. After preliminary testing, a 40 min period was chosen as of appropriate test period. No leakage of particles from the test-chambers was detected.

\section{Benzene}

Three replicates of fresh plants were used, as for the PM trials. XX Benzene was injected into the test chamber to achieve a concentration of $10 \mathrm{ppmv}$, and concentration reduction measurements taken using a portable MiniRae 3000-VOC detector (Rae Systems, Honeywell; Thermo Fisher Sci.; Melb. Aust.) . Since this contaminant was in vapour phase with no 
tendency to deposition, after preliminary testing a period of 12-hours was selected for the trials, with samplings at 3-hour intervals. Loss of benzene by chamber leakage was determined prior to all tests, and data corrected accordingly.

All data are presented as means \pm standard error (SE), and were analysed using SPSS version 21.0 (SPSS Inc., USA).

\section{RESULTS}

\section{$\mathbf{P M}_{10}$ removal}

The $\mathrm{PM}_{10}$ removal performance for modules containing C. comosum is shown in Figure 3a. It can be seen that the PM-only test-chamber control trials showed substantial precipitation of $\mathrm{PM}_{10}$, with a loss of $71.5 \pm 0.02 \%$ of particles over the $40 \mathrm{~min}$ test period. However, passive planted-modules showed a significantly higher $\mathrm{PM}_{10}$ removal $(\mathrm{p}<0.05$ unless stated otherwise), with $90.6 \pm 0.002 \%$ being removed over the same period; i.e. an almost $20 \%$ increase. In addition, for planted-modules with an airflow of $4.5 \mathrm{~L} / \mathrm{s}, \mathrm{PM}_{10}$ was reduced to $2.26 \pm 0.001 \%$ within $20 \mathrm{~min}$; and with an airflow of $9.0 \mathrm{~L} / \mathrm{s}, \mathrm{PM}_{10}$ was reduced to $3.32 \pm$ $0.01 \%$ in $\sim 10 \mathrm{~min}$. Thus, with either airflow, the planted-modules were capable of removing $\mathrm{PM}_{10}$ concentrations to below the laboratory ambient level of $20 \pm 2.5 \mathrm{ppb}$.

The results for modules containing E. aureum are shown in Figure 3b. Contaminant-only control test-chamber $\mathrm{PM}_{10}$ precipitation rates were similar to those obtained with $C$. comosum. With passive planted-modules, $86.2 \pm 0.03 \%$ removal of $\mathrm{PM}_{10}$ over 40 min was observed. From this result, it would seem that the different foliage structures of these two species tested had little effect on $\mathrm{PM}_{10}$ removal rates. With both species, and either rate of airflow, $\mathrm{PM}_{10}$ removal down to approximately $1.0 \%$ was attained within 15 min.

\section{$\mathbf{P M}_{2.5}$ removal}

Figure $4 \mathrm{a}$ shows rates of reduction of $\mathrm{PM}_{2.5}$ with $C$. comosum plant-wall modules. The contaminant-only chamber control treatment resulted in a reduction of $68.3 \pm 0.02 \%$ over the 40 min period. With passive planted-modules, a reduction of $86.2 \pm 0.02 \%$ was recorded over the test period. With a $4.5 \mathrm{~L} / \mathrm{s}$ airflow, concentrations were reduced to zero in $20 \mathrm{~min}$., and with a $9.0 \mathrm{~L} / \mathrm{s}$ airflow, levels were lowered to zero in $15 \mathrm{~min}$. For $\mathrm{PM}_{2.5}$ trials with E. aureum, the control treatment loss (Figure 4b) showed similar results over the $40 \mathrm{~min}$ period to those with $C$. comosum. Also, with passive modules a removal of $89.4 \pm 0.02 \%$ was obtained. With a fan output of $4.5 \mathrm{~L} / \mathrm{s}$ concentrations were reduced to zero in $20 \mathrm{~min}$, and with the $9 \mathrm{~L} / \mathrm{s}$, to zero in $\sim 10 \mathrm{~min}$.

Overall the results with the two species showed very similar patterns in removal of both $\mathrm{PM}_{10}$ and $\mathrm{PM}_{2.5}$ (Figs 3 and 4). Passive planted-modules showed an approximately $20 \%$ higher reduction rate than in control chambers; and with the operation of module fans, rates of removal were at least doubled over the control treatment. 

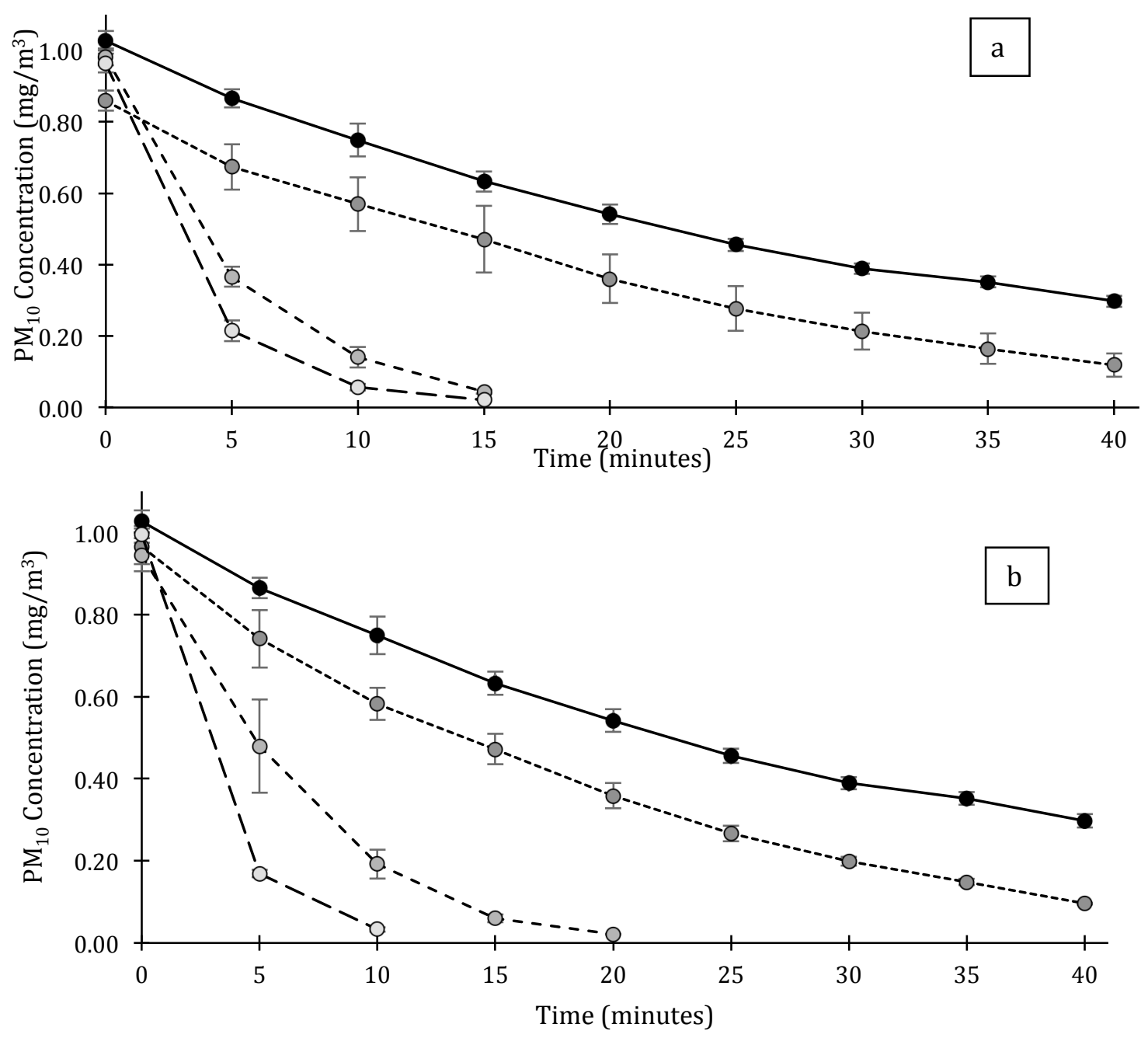

$\longrightarrow$ Chamber control $\quad---$--- No ventilation
$--0--7.5 \mathrm{~L} / \mathrm{s}$ ventilation $\quad-\bullet-15.0 \mathrm{~L} / \mathrm{s}$ ventilation

Figure 3: Test-chamber trials of green-wall $\mathrm{PM}_{10}$ removal, at 3 substrate airflow rates, with: (a) C. comosum; (b) E. aureum. (Means $\pm \mathrm{SE}, \mathrm{n}=3$ )

\section{Benzene Removal}

\section{C. comosum}

With passive planted-modules, benzene was rapidly removed over the first 3-hours of the test period, after which a much slower rate of reduction was observed, with a final $53 \pm 06 \%$ removal being recorded over the 12-hour period (Fig. 5a; data corrected for chamber leakage). In contrast with the results of the PM trials, the added airflow of $9.0 \mathrm{~L} / \mathrm{s}$ through the modules lowered the rate of benzene reduction, with only a $30.5 \pm 0.7 \%$ removal over the 12 hour period (leakage corrected). 

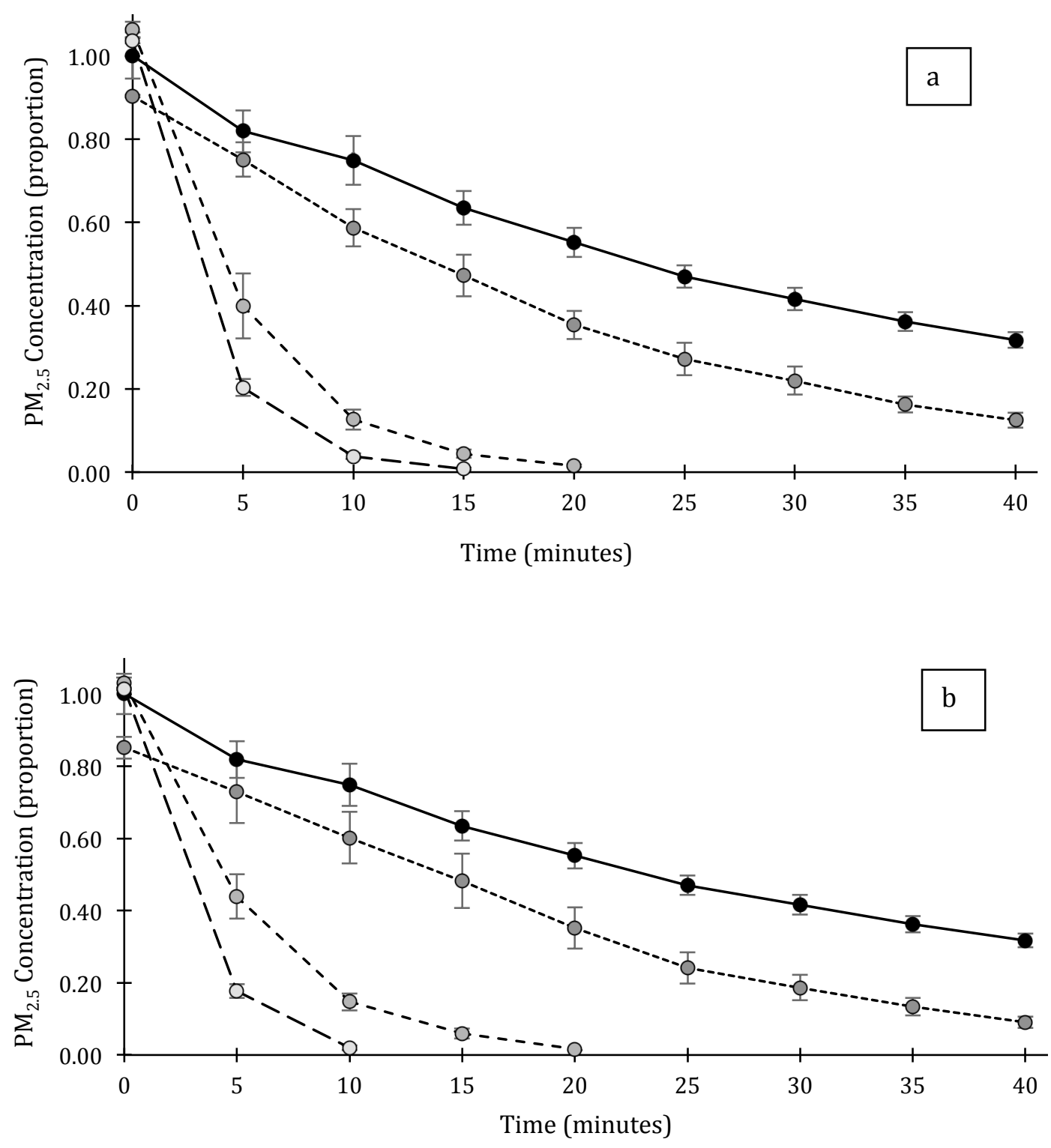

$\longrightarrow$ Chamber control $\quad--$--- No ventilation
--০- - 7.5 L/s ventilation $\quad-\bullet-15.0 \mathrm{~L} / \mathrm{s}$ ventilation

Figure 4: Test-chamber trials of plant-wall $\mathrm{PM}_{2.5}$ removal, at 3 substrate airflow rates, with: (a) C. comosum; (b) E. aureum. (Means $\pm \mathrm{SE}, \mathrm{n}=3$ ) 


\section{E. aureum}

Rates of benzene removal with this species (Fig. 5b) were very similar to those obtained with C. comosum. With passive planted-modules, the concentration was decreased by $53.7 \pm 0.08 \%$ over the 12-hour test period (leakage-corrected). Nevertheless, this was significantly higher than that recorded for modules with an airflow of $9.0 \mathrm{~L} / \mathrm{s}$, which yielded a benzene reduction of only $42 \pm 1.2 \%$.

\section{DISCUSSION}

\section{PM removal}

No significant differences in PM removal rates were found between the two plant species trialed, although they are members of phylogenetically and phenotypically disparate monocot orders. With passive planted-modules, reductions were significantly faster than with contaminant-only chamber control rates, while removal rates with active aeration were considerably higher. With airflows of either $4.5 \mathrm{~L} / \mathrm{s}$ or $9.0 \mathrm{~L} / \mathrm{s}$ through the $0.25 \mathrm{~m}^{2}$ modules, both $\mathrm{PM}_{10}$ and $\mathrm{PM}_{2.5}$ concentrations were reduced to low levels within $50 \%$ or less of the time taken in the control trials.

There appear to have been no studies of the effects on PM deposition on indoor plant-walls. It is recognised that small-particle deposition responds to surface roughness, with greater surface complexity resulting in greater removal. The coconut-fibre substrate in the green-wall system tested here would also act as a filter-collector, some of the PM lodging in the fibrous material, through boundary layer deposition or adhesion to substrate particles. Specialised mechanical air-filters, such as high efficiency particulate air (HEPA) filters, use a range of pore sizes to trap differently sized particles, with some filters effective in reducing the entry of particles smaller than $\mathrm{PM}_{2.5}$ (Barnes, 2010; Spilak et al., 2014). It seems likely that substrate pore size range of indoor plant-walls could be a second determinant of their PM removal efficiency. It has been estimated (Brewer, 1964; Deepagoda et al 2013) that a fibrous filter would need micro-pores of 5-30 $\mu \mathrm{m}$ for removal of $\mathrm{PM}_{10}$, and ultramicro-pores of 0.1$5 \mu \mathrm{m}$ for effective $\mathrm{PM}_{2.5}$ reduction. Overall, it seems that, for commercial and public buildings in inner city areas, indoor plant-walls could benefit occupants by reducing PM concentrations.

\section{Benzene removal}

The increasing introduction of green plants in urban centres, both outside and indoors, can play a significant role in mitigating urban VOC pollution. VOC bioremediation occurs primarily through the bacterial activity of the rhizosphere, the substrate microflora utilising VOCs as a carbon source (Wood et al. 2002; Ward et al. 2003; Atlas and Hazen 2011). There is a substantial literature demonstrating the ability of indoor plants, potted or hydroponic, to reduce concentrations of benzene, making it one of the most frequently tested organic air 

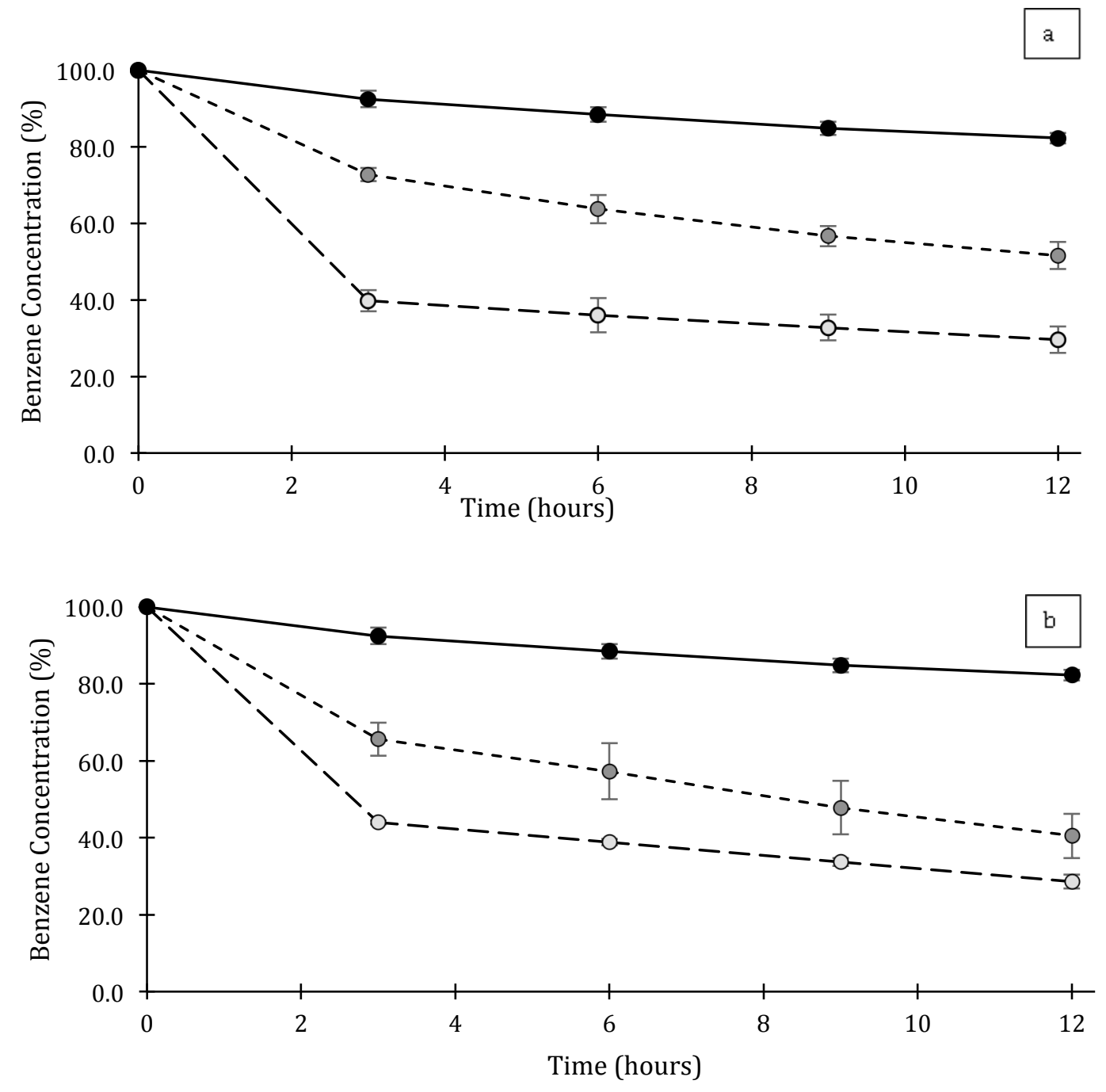

-๑- No ventilation --๑- $15.0 \mathrm{~L} / \mathrm{s}$ ventilation $\longrightarrow$ Chamber control

Figure 5: Test chamber trials of plant-wall benzene removal, at two substrate ventilation airflow rates: (a) C. comosum; (b) E. aureum. (Means $\pm \mathrm{SE}, \mathrm{n}=3$ )

contaminants (e.g., Wood et al., 2002, 2006; Orwell et al., 2006; Apte and Apte 2010; Irga et al., 2013; Dela Cruz et al. 2014). Research in our laboratory has shown that if the benzene concentration is raised, so does the removal rate, the process approaching first-order kinetics (Orwell et al 2006).

Compared with benzene removal rates in passive planted-modules, an active airflow of 9.0 $\mathrm{L} / \mathrm{s}$ resulted in significantly decreased rates of VOC reduction. Several factors may have been involved. Substrate airflows will lead to an increase in water evaporation from the substrate, 
which may have harmed the metabolic ability of the rhizosphere microbial communities. Also, increased airflow may reduce the impact and retention of benzene molecules on bacterial membranes (see Krometis et al 2009), hence decreasing the efficiency of its absorption and degradation. Additional air turbulence within the test-chamber would also have disrupted the concentration gradient between the site of degradation, the substrate, and the chamber atmosphere, leading to reductions in VOC reductions. There have been no previous reports on the relationship between airflows and bacterial VOC degradation. The issue requires further study.

In summary, this pilot study demonstrates that indoor green-wall components can significantly reduce concentrations of $\mathrm{PM}_{10}$ and $\mathrm{PM}_{2.5}$, and that the addition of an airflow through the substrate/ rhizosphere can significantly increase its PM reduction efficiency. It has also been shown that green-wall modules can reduce benzene concentrations, although with this VOC at least, increased airflow reduced the system's removal capacity. The findings indicate that indoor plant-walls have the potential to lower indoor air pollution levels, hence improving indoor environmental quality (IEQ), and lowering loads on present air-conditioning systems.

\section{ACKNOWLEDGEMENTS}

We thank UTS colleagues Professor Margaret Burchett and Gemma Armstrong for their continued efforts in assisting and consultation with this research. Dr. Peter Irga and Peter Abdo provided editorial assistance and engineering expertise in determining airflow rates through the green walls. We also thank Mr. Jock Gammon, Junglefy Pty Ltd, for supplying resources for this project.

The authors declare they have no competing interests.

\section{LITERATURE CITED}

Abel, C. (2010) The vertical garden city: Towards new urban topology. CTBUH Jour.l 2:20-25.

Aitken, J. E., and Palmer, R. D. (1989) The use of plants to promote warmth and caring in a business environment. Proc. Ann Meet Amer Culture Assoc (St.Louis, MO) 1-29.

Apte, M. G., and Apte, J. S. (2010) A pilot study of the effectiveness of indoor plants for the removal of volatile organic compounds in indoor air of a seven-story office building. Lawrence Berkeley Nat Lab, Univ Calif.

Ashraful, A. M., Masjukih H. H., and Kalam M. A. (2015) Particulate matter, carbon emissions and elemental compositions from a diesel engine exhaust fuelled with diesel-biodiesel blends. Atmos Environ 120:463-474.

Atlas. R. M., and Hazen T. C. (2011) Oil Biodegradation and bioremediation: A tale of the two worst spills in U.S. history. Environ Sci Technol 45:6709-6715. 
Aust. Gov. Dept. Ind., Innov., Sci. (2011) The Bottom Line of Energy Efficiency. EEX.gov.au. Canb. ACT 2011. (http://eex.gov.au/technologies/heating-ventilation-and-air-conditioning accessed $(20 / 03 / 16)$.

Aydogan, A., and Montoya L. D. (2011) Formaldehyde removal by common indoor plant species and various growing media. Atmos Environ 45:2675-2682.

Bahadar, H., Mostafalou S., and Abdollahi M. (2014) Current understandings and perspectives on non-cancer health effects of benzene: A global concern. Toxicol Appl Pharmacol 276(2): 83-94.

Barnes, G. (2010) Effective stress and pore pressure. In, G. Barnes (Ed) Soil Mechanics: Principles and Practice, $3^{\text {rd }}$ Ed. Palgrave Macmillan, UK. Ch. 4:108-17.

Bernstein, J. A., Alexis, N., Bacchus, H., Bernstein, L., Fritz, P., Horner, E., Li, N., Mason, S., Nel, A., Oullette, J., Reijula, K., Reponen, T., Seltzer, J., Smith, A., and Tarlo, S. M. (2008) The health effects of nonindustrial indoor air pollution. J Allergy Clin Immunol 121:585-591.

Brewer, R. (1964) Fabric and Mineral Analysis of Soils. Wiley, NY pp. 970 -972.

Cheng, C. H., Cheung, C. S., Chan, T. L., Lee, S. C., and Yao, C. D. (2008) Experimental investigation on the performance, gaseous and particulate emissions of a methanol fumigated diesel engine. Sci Total Environ 389:115-124.

Chiesura, A. (2004) The role of urban parks for the sustainable city. Lands Urb Plan 68-138.

Darlington, A, Dat, J., and Dixon, M. (2001) The biofiltration of indoor air: Air flux and temperature influences the removal of toluene, ethylbenzene and xylene. Env Sci Tech 35:240-246.

Deepagoda, T. K., Lopez, J., Møldrup, P., de Jonge L, and Tuller, M. (2013) Integral parameters for characterizing water, energy, and aeration properties of soilless plant growth media. $J$ Hydrol 502:120-127.

Dela Cruz, M., Christensen, J. H., Thomsen, J. D., and Müller, R. (2014) Can ornamental potted plants remove volatile organic compounds from indoor air? A review. Environ Sci Pollut Res 21:13909-13928.

Dzierżanowski, K., Popek, R., Gawrońska, H., Sæbø, A., and Gawroński, S. W. (2011) Deposition of particulate matter of different size fractions on leaf surfaces and in waxes of urban forest species. Int $J$ Phytorem 13:1037-1046.

Escobedo, F. J., and Nowak, D.J. (2009) Spatial heterogeneity and air pollution removal by an urban forest. Lands Urban Plan 90:102-110.

Evuti, A. M. (2013) A synopsis of biogenic and anthropogenic volatile organic compounds emissions: Hazards and control. Internat J Eng Sci 2(5): 145-153.

Fann, N., Fulcher, C. M., and Hubbel, B. J. (2009) The influence of location, source, and emission type in estimates of the human health benefits of reducing a ton of air pollution. Air Qual Atmos Health 2:169-176.

Gonzalez, F. J., and Kimura, S. (2003) -Study of P450 function using gene knockout and transgenic mice. Arch Biochem Biophys 409:153-158. 
Industry Gov. Au. (2013) Factsheet Basics of HVAC Energy Efficiency. https://www.environment.gov.au/system/files/energy/files/hvac-factsheet-basics.pdf accessed $(12 / 10 / 16)$

Irga, P. J., Burchett, M. D., and Torpy, F. R. (2015). Does urban forestry have a quantitative effect on ambient air quality in an urban environment? Atmos Environ 32(2): 171-185.

Irga, P. J., Torpy, F. R., Burchett, M. D. (2013) Can hydroculture be used to enhance the performance of indoor plants for the removal of air pollutants? Atmos Environ 77:267-271.

Kearney, W. L., MacNeill, M., Xu, X., Van Ryswyk, K., You, H., Kulka, R., and Wheeler A. J. (2011) Residential indoor and outdoor ultrafine particles in Windsor, Ontario. Atmos Environ 45:7583-7593.

Knight, C., Haslam, S.A. (2010) The relative merits of lean, enriched, and empowered offices: An experimental examination of the impact of workspace managements on well-being and productivity. $J$ Exper Psychol 16:58-172.

Krometis, L., Drummey, P., Characklis, G., and Sobsey, M. (2009) Impact of microbial partitioning on wet retention pond effectiveness. J Environ Eng 135:758-767.

Kurniawan, A., and Schmidt-Ott, A. (2006) Monitoring the soot emissions of passing cars. Environ Sci Technol 40:1911-1915.

Llewellyn, D., and Dixon, M. (2011) Can plants really improve indoor air quality? Agric and Related Biotechs 4:331-338.

Loh, S. (2008) Living walls: A way to green the built environment. Environment Design Guide, 1 (TEC 26). Aust Inst Architects pp. 1-10.

Minnesota Dept. Health. (2017) Volatile Organic Compounds in Your Home, http://www.health.state.mn.us/divs/eh/indoorair/voc/ accessed (11/12/17).

Nowak, D. J., Crane, D. E., and Stevens, J. C. (2006) Air pollution removal by urban trees and shrubs in the United States. Urban For Urban Green 4:115-123.

NSW EPA (2015) Air NSW-Overview. http://www.epa.nsw.gov.au/air/ accessed (22/04/16).

NSW Health (2004) Comparison of personal exposure to pollutants by commuting mode in Sydney; BTEX \& $\mathrm{NO}_{2}:$ p.9.

NSW Health (2014) Particulate Matter $\left(\mathrm{PM}_{10}\right.$ and $\left.\mathrm{PM}_{2.5}\right)$ http://www.health./ nsw.gov. au/environment/air/Pages/particulate-matter.aspx accessed (04/04/16).

Orwell, R. L., Wood, R. A., Burchett, M. D,. Tarran, J., and Torpy, F. (2006) The potted-plant microcosm substantially reduces indoor air VOC pollution: II. Laboratory study. Water Air Soil Pollut 177:59-80.

Pérez-Urrestarazu, L., Fernández-Cañero, R,. Franco, A., Egea A. G. (2016) Influence of an active living wall on indoor temperature and humidity conditions. Ecol Eng 90:120-124

Pilon-Smits, E. (2005) Phytoremediation. Annu Rev Plant Biol 56:15-39.

Soreanu, G., Dixon, M., and Darlington, A. (2013) Botanical biofiltration of indoor gaseous pollutants - Mini-review. Chem Eng J 229:585-594. 
Smith, M. T. (2010) Advances in understanding benzene health effects and susceptibility. Annu Rev Pub Health 31:133-148.

Spilak, M. P., Karottki, G. D., Kolarik, B., Frederiksen, M., Loft, S., and Gunnarsen, L. (2014) Evaluation of building characteristics in 27 dwellings in Denmark and the effect of using particle filtration units on $\mathrm{PM}_{2.5}$ concentrations. Build Environ 73:55-63.

Tarran, J., Torpy, F., Burchett, M. D. (2007) Use of living pot-plants to cleanse indoor air - research review. Proc. 6th Internat. Conf. on IAQ, Ventiln., Energy Conserv.: Buildings - Sustainable Built Environ, Sendai, Japan 249-256.

Torpy, F., Irga P. J., and Burchett, M. D. (2014) Profiling indoor plants for the amelioration of high $\mathrm{CO}_{2}$ concentrations. Urban For Urban Greening 13:213-227.

UNDESA (2015) The World Population Prospects: 2015, Revision 2015. http://www.un.org/en/development/desa/publications/world-population-prospects-2015-revision.html accessed (23/04/16).

USEPA (2014) Air Pollution: Current and Future Challenges. 2014. http://www.epa.gov/clean-air-actoverview/air-pollution-current-and-future-challenges. (accessed (08/04/16).

USEPA (2016) Criteria Air Pollutants. http://www.epa.gov/criteria-air-pollutant. (Accessed 03/04/2016).

USEPA (2017) Volatile Organic Compounds' Impact on Indoor Air Quality. www.epa.gov/indoor-air-quality-iaq/volatile-organic-compounds-impact-indoor-air-quality accessed (01/08/2017).

Ward, O., Singh, A., and Van Hamme, J. (2003) Accelerated biodegradation of petroleum hydrocarbon waste. J Ind Microbiol Biotechnol 30:260-270.

Wheeler, A. J., Wong S. L., Khoury, C., and Zhu, J. (2013) Predictors of indoor BTEX concentrations in Canadian residences. Health Reports (Stats Canada) 24:11-17.

WHO (2010) Guidelines for Indoor Air Quality: Selected Pollutants. www.euro. who.int $\% 2 \mathrm{~F}$ data $\% 2$ Fassets $\% 2 \mathrm{Fpdf}$ file $\% 2 \mathrm{~F} 0009 \% 2 \mathrm{~F} 128169 \% 2 \mathrm{Fe} 94535$.pdfandusg=AFQjCNHSk Zok2jG22V47KeGkpD0hzm8Q1Aandbvm=bv.121099550,ddG accessed (15/04/16).

WHO (2013) Health effects of particulate matter: Policy implications for countries in eastern Europe, Caucasus and central Asia. http://www.euro.who.int/en/health-topics/environment-and-health/airquality/publications/2013/health-effects-of-particulate-matter.-policy-imp. accessed (08/04/2016).

Wolverton, B. C., Wolverton, J. D. (1993) Plants and soil microorganisms: removal of formaldehyde, xylene, and ammonia from the indoor environment. J Mississippi Acad Sci 38:11-15.

Wong, N. H., Tan, A., Tan, P. Y., Chiang, K., and Wong, N C. (2010) Acoustics evaluation of vertical greenery systems for building walls. Build Environ 45:411-420.

Wood, R. A., Orwell, R. L., Tarran, J., Torpy, F., and Burchett, M. D. (2002) Potted-plant/growth media interactions and capacities for removal of volatiles from indoor air. $J$ Hort Sci Biotech 77:120129. 
Wood, R. A., Burchett, M. D., Alquezar, A., Orwell, R., Tarran, J., and Torpy, F. (2006) The pottedplant microcosm substantially reduces indoor air VOC pollution: I. Office field-study. Water Air Soil Pollut 175:163-80.

Yang, D. S., Pennisi, S. V., Son, K., and Kays, S. J. (2009) Screening indoor plants for volatile organic pollutant removal efficiency. Hort Sci 44:1377-81.

Zhang, J., and Smith, K. R. (2003) Indoor air pollution: a global health concern. British Medical Bulletin 68:209-225. 